\author{
KONRAD BIELECKI \\ https://orcid.org/0000-0001-9156-1388 \\ Instytut Historii PAN, Warszawa
}

\title{
ETNOCENTRYZM: CZY TYLKO JEDEN? KRYTYCZNA ANALIZA TEORII „RENESANSÓW” JACKA GOODY’EGO*
}

\begin{abstract}
Abstrakt: Tekst jest krytyczną analizą teorii „renesansów” Jacka Goody’ego: bliżej przyglądam się temu, jak autor rozumiał epokę odrodzenia oraz powiązane $\mathrm{z}$ nią zjawiska. Dekonstrukcja jego twierdzeń, osadzona w szerszej krytyce strukturalistycznej historii globalnej, uwidacznia niedobory takiego podejścia i jego nieskuteczność w przełożeniu na bardziej szczegółowe studia przypadku.
\end{abstract}

Słowa kluczowe: studia nad renesansem, strukturalizm, historia globalna, historia uniwersalna, badania porównawcze.
Abstract: The text is a critical analysis of Jack Goody's theory of renaissances, which takes a closer look at how the author understood the renaissance and related phenomena. The deconstruction of the author's statements, set in a broader critique of structuralist global history, reveals the shortcomings of this approach and its ineffectiveness in more detailed case studies.

Keywords: Renaissance studies, structuralism in historiography, global history, universal history, comparative research.

Zmarły niedawno sir Jack Goody (1919-2015), brytyjski antropolog społeczny związany z St John's College w Cambridge, zasłynął badaniami nad kulturowym znaczeniem piśmienności ${ }^{1}$ oraz badaniami nad organizacją oralnych społeczeństw Afryki ${ }^{2}$. Polskiemu czytelnikowi znany jest z kilku

* Za wnikliwą lekturę, uwagi i poprawki do tekstu chciałbym gorąco podziękować Ewie Domańskiej, Alicji Kosterskiej, Maciejowi Janowskiemu, Adamowi Manikowskiemu oraz Tomaszowi Wiśliczowi.

${ }^{1}$ J. Goody, Literacy in Traditional Societies, Cambridge 1968.

2 J. Goody, Economy and Feudalism in Africa, „Economic History Review” 22, 1969, 3, s. 393-405; idem, Technology, Tradition, and the State in Africa, London 1974. 
prac wydanych w ciągu ostatnich lat. Poza uznanym dziełem Logika pisma a organizacja społeczeństwa (2006), na szczególną uwagę zasługują przekłady dwóch jego ostatnich książek. Pierwszą z nich jest Renesans czy tylko jeden? ${ }^{3}$. Podczas lektury tej pozycji szybko przekonałem się, że aby zrozumieć zawarte $\mathrm{w}$ niej próby zredefiniowania tak renesansu jako pojęcia określającego formację kulturową, jak i jego wpływu na powstanie nowoczesnego świata, należy osadzić je w szerszym kontekście twórczości Goody’ego. Sięgnąłem zatem po wcześniejszą, wydaną w 2007 r., książkę zatytułowaną w polskim tłumaczeniu Kradzież historii ${ }^{4}$. Okazało się, że obie pozycje tworzą wzajemnie uzupełniający się wykład poglądów autora na temat eurocentrycznego postrzegania przeszłości, wynikającego z zastałego w zachodniej historiografii przekonania o „europejskiej unikalności". W pracach tych Goody krytykuje próby zawłaszczenia przez cywilizację Zachodu wartości, które, jak twierdzi, są właściwe dla każdej kultury piśmiennej. Zawłaszczenie ma zachodzić na polu nowoczesnych nauk społecznych, takich jak socjologia, antropologia i historia. Goody podważa wyjątkowość Zachodu, która swymi korzeniami miałaby sięgać co najmniej wieku XV, jednocześnie próbuje przywrócić należyte miejsce na drodze ku nowoczesności wielkim cywilizacjom Wschodu ${ }^{5}$. $\mathrm{W}$ tym celu proponuje postrzeganie renesansu jako zjawiska socjoekonomicznego, jednocześnie uznając renesans historyczny za w dużej mierze historiograficzny mit ${ }^{6}$ początku światowej przewagi Zachodu.

Rozważania te wpisują się w nurt nowej historii globalnej ${ }^{7}$, mającej na celu odrzucenie przekonania o europejskiej dominacji przed XIX w. i dekonstrukcję eurocentrycznej interpretacji historii. Nowa historia globalna sytuuje się w ambiwalentnej relacji do historiografii modernistycznej. I tak Goody z jednej strony korzysta z kategorii wielkich struktur,

${ }^{3}$ J. Goody, Renesans czy tylko jeden?, Warszawa 2012. Wyd. oryg. Renaissances. The One or the Many?, Cambridge 2010.

${ }^{4}$ J. Goody, Kradziez historii, Warszawa 2009. Wyd. oryg. The Theft of History, Cambridge 2007.

${ }^{5}$ Zagadnienie wpływu wielkich cywilizacji wschodnich na współczesność zarysował także we wcześniejszej pracy: J. Goody, Capitalism and Modernity. The Great Debate, Cambridge 2004 (polskie wyd. 2010).

${ }^{6}$ Choć Goody raczej niechętnie odnosił się do twórczości Petera Burke’a, koncepcję renesansu jako mitu historiograficznego możemy znaleźć także w: P. Burke, Renesans, Kraków 2009 (oryg. 1964), s. 2 nn.

7 Do najbardziej rozpoznawalnych prac w tym nurcie należą: J.L. Abu-Lughod, Europa na peryferiach. Średniowieczny system-świat w latach 1250-1350, Kęty 2012 (oryg. ang. 1989), oraz E.R. Wolf, Europa i ludy bez historii, Kraków 2009 (oryg. ang. 1982). Goody odnosi się do teorii Wolfa w Kradzieży historii, korzystając przede wszystkim z fragmentów o państwie trybutarnym jako alternatywie dla europejskiego pojęcia feudalizmu. 
wywodzących się z tradycji historii społeczno-gospodarczej, z drugiej zaś odnosi się krytycznie do anachronizmu, który ostatecznie ogranicza wszelkie makroanalizy do pytania: „dlaczego Europa zdominowała świat?". Założenia te realizuje, wprowadzając nową kategorię różnych „renesansów”, które miałyby występować we wszystkich kulturach piśmiennych. Według niej, „odrodzenie” przestaje być zjawiskiem czysto historycznym. Goody twierdzi, że tylko społeczeństwa zdolne do zachowania swoich idei w formie materialnej i przekazania ich w przyszłość, są w stanie spoglądać wstecz i jednocześnie się rozwijać. By w danej kulturze, wykazującej taką zdolność, mogło dojść do „odrodzenia”, muszą zostać spełnione kolejne socjoekonomiczne warunki, to jest nastanie okresu szeroko rozumianej prosperity gospodarczej, generującej z kolei akumulację kapitału oraz odpowiednie ilości wolnego czasu. Tak zrekonfigurowane pojęcie renesansu, dzięki uwolnieniu go od eurocentrycznego kontekstu historycznego (rozumianego jako włoskie odrodzenie wraz z jego ogólnoeuropejskimi konsekwencjami), staje się zjawiskiem socjologicznym, osiągalnym dla każdej kultury po wystąpieniu takiego splotu zjawisk9 . Idąc tym tropem, Goody odnajduje przeróżne okresy w dziejach wielkich cywilizacji Bliskiego i Dalekiego Wschodu, noszące znamiona „odrodzenia”. Jednocześnie postuluje, żeby w dziejach Starego Kontynentu epokę pomiędzy XV a końcem XVI w. rozpatrywać bardziej lokalnie i nie doszukiwać się w niej korzeni globalnych nowoczesności i kapitalizmu.

Moje wątpliwości wzbudziły przede wszystkim metody wykorzystane do udowodnienia powyższych tez. Goody, opierając się na swoich doświadczeniach z badań nad relacją pomiędzy oralnością a piśmiennością, zdolność do materialnego zachowania własnej przeszłości uznaje za czynnik decydujący o możliwości wystąpienia „renesansu”. Jak postaram się wykazać, tak zdekontekstualizowane pojęcie może co prawda objąć więcej zjawisk oddalonych od siebie czasowo i przestrzennie w perspektywie porównawczej, ale stawianie znaku równości między kulturami, wyabstrahowanymi od własnych historyczności, ignoruje te spośród ich osiągnięć, które wymykają się wartościom bliskim zachodniej humanistyce. Takie działanie paradoksalnie utrwala europejski materialistyczny

${ }^{8}$ Koncepcje wielkich studiów porównawczych oraz długiego trwania Goody zawdzięcza Fernandowi Braudelowi, szczególnie trzytomowemu dziełu Kultura materialna, gospodarka i kapitalizm XV-XVIII wiek, t. 1-3, red. nauk. J. Kochanowicz, Warszawa 1992 (oryg. franc. 1979). Poświęcił mu krytyczny rozdział w Kradzieży historii, w którym pada zarzut o brak dowodów popierających tezę o statyczności miast Wschodu w porównaniu z „niezwykłą zmiennością” europejskich metropolii w późnym średniowieczu i później. Patrz: J. Goody, Kradzież historii, s. 192-208.

9 J. Goody, Renesans, s. 308. 
etnocentryzm, zamyka bowiem zjawiska społeczno-gospodarcze i kulturalne na osi rozwoju, na której każde osiągnięcie ma przypisaną wartość, negatywną bądź pozytywną, w zależności od uznaniowej kategorii „postępowości", która staje się tutaj kluczowym wyznacznikiem oceny przeszłości. Uznając zatem cywilizacje Dalekiego i Bliskiego Wschodu za zdolne do osiągnięcia kapitalizmu i nowoczesności, poprzez dobór niektórych zjawisk występujących w tych cywilizacjach, Goody nie dekonstruuje dyskursu eurocentrycznego, a dokonuje właściwie kolejnej arbitralnej oceny.

Niniejszy tekst będzie zatem próbą krytycznej analizy teoretycznych założeń Jacka Goody'ego, wpisujących się w propozycje nowej historii globalnej. Moim celem nie było sugerowanie innych rozwiązań dla tej dyscypliny; nie sądzę, ażeby było to potrzebne. Strukturalizm jako narzędzie opisu dziejów ludzkości wyczerpał już, jak jestem głęboko przekonany, zasób możliwych interpretacji. $Z$ kolei historia kulturowa, w ostatnich dekadach ugruntowana w historiografii powszechnej, sytuująca się, jak pisał Peter Burke ${ }^{10}$, gdzieś pomiędzy idealizmem i materializmem, daje bardzo obiecujące wyniki, często zmieniając obowiązującą perspektywę patrzenia na przeszłość.

\section{Pojęcie renesansu i pismo}

Czy renesans otworzył Europie drogę do modernizacji? Czy był kluczowym etapem umożliwiającym powstanie kapitalizmu i nowoczesności? Czy bez niego Zachód zdominowałby świat w XIX w.? Na te pytania, nurtujące historyków od stuleci, udzielano diametralnie różnych odpowiedzi, a trwająca do dziś dyskusja nie doprowadziła do jednoznacznych wniosków. Okres wielkiego optymizmu, kiedy to badacze byli przekonani o możliwościach wytworzenia obiektywnej metody wykorzystującej narzędzia kwantytatywne w ramach historii społeczno-gospodarczej ${ }^{11}$, pozwalającej na udzielenie ostatecznych odpowiedzi, nie przyniósł jednak pełnych rozwiązań, choć otworzył nowe pola dyskusji. Badacze coraz chętniej zwracali się ku rozważaniom teoretycznym, a przedmiotem ich

10 P. Burke, Kultura i społeczeństwo w renesansowych Włoszech, Warszawa 1991 (oryg. ang. 1972), s. 10-12.

${ }^{11}$ Za twórców tej szkoły uznawani są François Simiand i Ernest Labrousse. Historię społeczno-gospodarczą rozumiem tu dwuaspektowo, za Wojciechem Wrzoskiem, jako „uhistorycznienie ekonomii” oraz „ekonomizowanie historii”. Z perspektywy niniejszego artykułu z pewnością najważniejszym przedstawicielem tego nurtu był Fernand Braudel; patrz W. Wrzosek, Historia - kultura - metafora. Powstanie nieklasycznej historiografii, Wrocław 1995, s. 56-76, 77-92. 
zainteresowania stały się bardziej sposoby interpretowania niż sama interpretacja. Takie podejście, w obliczu nierozwiązywalności pewnych kwestii, zachęcało uczonych do poszukiwania nowych pojęć lub reinterpretowania znaczeń terminów już funkcjonujących w obiegu naukowym.

Podstawowym problemem w dyskusji o renesansie jest sama niejednoznaczność tego terminu, który nabywał coraz to nowszych znaczeń w swoim długim trwaniu. Nazwanie całej epoki renesansem - po raz pierwszy w Histoire de France autorstwa Jules'a Micheleta (1855) - otworzyło proces wynoszenia odrodzenia do pozycji zjawiska decydującego w dziejach Europy i świata. Najsłynniejszą próbą wykorzystania takiego znaczenia tego pojęcia była oczywiście Die Kultur der Renaissance in Italien Jacoba Burckhardta z 1860 r. Jak zauważył Burke, rozumienie renesansu w tym klasycznym opracowaniu sprowadzić można do dwóch podstawowych cech - „indywidualności” i „nowoczesności”12. We wstępie do rozdziału „Państwo włoskie a jednostka”, co znamienne, otwierającego dzieło, Burckhardt pisał o przekształceniu się Włochów w ludzi nowoczesnych (uznając ich przy tym za wyprzedzających pod tym względem pozostałych Europejczyków) dzięki wykształceniu się indywidualizmu ${ }^{13}$. Istotne jest tutaj samookreślanie się jako jednostka, samoświadoma swojej autonomii w stosunku do reszty społeczeństwa, mogąca na to społeczeństwo wywierać wpływ. U Burckhardta zatem indywidualny geniusz stawiany jest w pozycji siły napędowej przemian włoskiego renesansu. Interpretacja ta, ograniczona terytorialnie i czasowo do Włoch XV i XVI w., dla klasycznej historiografii stała się następnie matrycą analityczną dziejów Starego Kontynentu.

W centrum krytyki przeprowadzonej przez Goody'ego znajduje się teleologiczny wymiar takiego podejścia. Opierając się na teorii Jerry'ego Brottona ${ }^{14}$, uznał on renesans za mit stworzony na rzecz procesu sankcjonowania europejskiej dominacji. Najpierw nastąpiło przejęcie semantyczne sposobów określania czasu i przestrzeni, poprzez narzucenie metod periodyzacji dziejów oraz rysowania map, możliwych dzięki uprzedniemu rozwojowi pisma ${ }^{15}$. Te narzędzia zostały następnie wykorzystane do opisu dziejów własnej cywilizacji z zachowaniem nieprzerwanej ciągłości rozwoju, to jest w przypadku Europy od starożytności

12 P. Burke, Renesans, s. 1.

${ }^{13}$ J. Burckhardt, Kultura odrodzenia we Włoszech. Próba ujęcia, Warszawa 1991 (oryg. niem. 1860), s. 97.

${ }^{14}$ J. Brotton, The Renaissance Bazaar. From the Silk Road to Michelangelo, Oxford 2002; J. Goody, Kradzież historii, s. 139.

${ }^{15}$ J. Goody, Kradzież historii, s. 24. 
do kapitalizmu. Tak skonstruowane narzędzie dominacji, nazwane przez Goody'ego „kradzieżą historii”, pozwala zmonopolizować pożądane zjawiska kulturowe - szczególnie osiągnięcia antyku i jego odrodzenia w XV-XVI w. - i uznać je za elementy wyłączne dla własnej historyczności ${ }^{16}$.Każdy kolejny etap rozwoju zostaje zamknięty w związki przyczynowo-skutkowe, dzięki którym można przenosić początki dominacji czy wyższości cywilizacyjnej na długo wcześniej, niż wystąpiły ich realne objawy. Tak skonstruowana periodyzacja dziejów Europy sytuuje renesans w roli epoki rozpoczynającej pochód ku nowoczesności, który miał stać się możliwy właśnie dzięki staraniom pokoleń geniuszy-indywidualistów.

„Renesans" Goody'ego miałaby zostać odmitologizowany i sprowadzony do zjawiska wynikającego z rozwoju instytucji pisma. Umożliwiała ona fundamentalny w procesie odradzania się kultury gest - spojrzenie wstecz, dostęp do starożytnych pism, a co za tym idzie wiedzy, wzorców estetycznych oraz filozofii. Trwałość kultury piśmiennej łączy odrodzenie ze światem pożądanych wzorców - kulturą antyku, bez względu na realne związki pomiędzy dwiema oddalonymi od siebie w czasie formacjami. By jednak powyższy system miał sens, oba okresy muszą zostać przedzielone czasem zawieszenia w funkcjonowaniu tych wzorców. Wyjątkowości renesansu europejskiego, w sensie historycznym, od końca XIV w. aż po początek wieku XVII, Goody doszukiwał się w tym, co go bezpośrednio poprzedzało - w skrajnym upadku cywilizacji, za jaki uznawał średniowiecze. Zanik wzorców kulturowych miał obejmować wszelkie obszary działalności ludzkiej. W rozdziale „Montpellier i medycyna w Europie"17, autor rozpościera przed nami wizję potężnego regresu w wiedzy medycznej w pierwszych wiekach po upadku imperium rzymskiego. Jej odrodzenie w ośrodkach takich jak najpierw Salerno, a później Montpellier, odbyć się miało poprzez przejęcie wzorców starożytnych za pośrednictwem kultury arabskiej, wraz z wszelkimi udoskonaleniami. To zapośredniczenie miało potwierdzać utratę kontaktu Europejczyków z wiedzą antyczną, czyli głęboki upadek medycyny w średniowieczu. Tak w tym przypadku, jaki i innych dziedzinach kultury, Goody utożsamia regres z zapanowaniem chrześcijaństwa - wielkiej religii monoteistycznej odrzucającej pluralizm religijny i dążącej w swoich założeniach do całkowitej hegemonii ${ }^{18}$. Zatem drogą do odzyskania wiedzy starożytnej było nie tylko spojrzenie w głąb własnej przeszłości, ale także zwrócenie

\footnotetext{
${ }^{16} \mathrm{~J}$. Goody, Renesans, s. 311.

17 Ibidem, s. 62-85.

18 Ibidem, s. 23.
} 
się do dziedzictwa kulturowego cywilizacji islamu. Umożliwiać to miała przynajmniej częściowa sekularyzacja, pozwalająca na czerpanie wzorców z kultur uznanych za pogańskie czy heretyckie ${ }^{19}$.

\section{Między materializmem a ideą}

Ożywienie w nauce i sztuce Goody łączy bezpośrednio z rozwojem społeczno-ekonomicznym oraz postępem technicznym ${ }^{20}$. Rozwój nowych idei wynikać miał z rozprzestrzeniania się pism filozoficznych oraz akumulacji dóbr, możliwych dzięki rozwojowi miast, handlu i dalekomorskiej żeglugi ${ }^{21}$. Ta koncepcja historiograficzna opiera się na pozornie sprzecznych ze sobą orientacjach metodologicznych, jeśli nie ideologicznych. $Z$ jednej strony jest to marksowski materializm dialektyczny. U Goody'ego opiera się on na uznaniu wszelkich idei za wtórne wobec warunków materialnych. Z drugiej strony, da się dostrzec wpływy koncepcji liberalizmu ekonomicznego. Uwidacznia się to m.in. w stosunku Goody'ego do relacji między klasami wyższymi a nizinami społecznymi. Uważał on bowiem, że owoce prosperity renesansu, tak materialne, jak i wtórne wobec nich idee, choć początkowo dawały korzyści tylko warstwom uprzywilejowanym, z czasem „przesączały się w dół”22. Metafora ta, wywodząca się od neoliberalnego mitu "skapywania bogactwa” (ang. trickle-down theory), ma na celu spłaszczenie niewygodnego zjawiska, jakim była względna obojętność większości społeczeństwa wobec przełomowych idei. Jak zauważa Burke, na większość ludności Włoch (liczącej od 9 do $10 \mathrm{mln}$ ) odrodzenie nie wywarło prawdopodobnie najmniejszego wpływu ${ }^{23}$.

Ta niespodziewana zgodność teorii marksistowskiej z liberalną wynika z pojmowania materialnych warunków funkcjonowania społeczeństw

19 Ten aspekt badacz podkreśla niezwykle często, w sekularyzacji dopatrując się głównej siły postępu, zob. J. Goody, Kradzież historii, s. 132, 162-163 nn.; idem, Renesans, s. 30, 71-76, cały rozdział „Religia a świeckość”, s. 86-124, $328 \mathrm{nn}$.

${ }^{20}$ Znamienne, że Goody, mimo dużej uwagi poświęconej piśmienności, całkowicie niemal pomija rozwój druku i jego konsekwencje w zakresie komunikacji, których znaczenie podkreślają niemieccy badacze: J. Burkhardt, Stulecie reformacji w Niemczech (1517-1617). Między rewolucją medialna a przełomem instytucjonalnym, Warszawa 2009 (oryg. niem. 2002); M. Giesecke, Der Buchdruck in der frühen Neuzeit. Eine historische Fallstudie über die Durchsetzung neuer Informations- und Kommunikationstechnologien, Frankfurt am Main 1994. Za powyższą uwagę dziękuję recenzentom.

${ }^{21}$ J. Goody, Renesans, s. 95.

22 Ibidem, s. 317.

${ }^{23}$ P. Burke, Kultura i społeczeństwo, s. 7. 
jako kategorii analitycznej, do których odnosi się tak marksizm, jak i neoliberalizm. Warunki te w pierwszym przypadku stają się przyczyną, w drugim skutkiem konkretnych idei. Abstrahując od filozoficznego stosunku marksistów i liberałów do materializmu (szczególnie w relacji materia - idea), który bywa często odmienny, w opartych na tych nurtach rozważaniach historiograficznych kategoria ta zdaje się odgrywać kluczową rolę. Gospodarcza prosperity, na obu krańcach ideologicznego spektrum, innowacja, dominacja przemysłowa i militarna, bez względu na to, czy są wynikiem wyznawanych przez daną kulturę wartości, czy dopiero tworzą warunki do powstania nowego prądu myślowego, mają być głównymi wyznacznikami jakości danej cywilizacji w globalnej hierarchii rozwoju.

Goody, podziwiając osiągnięcia „azjatyckiej” - wymiennie traktowanej jako chińska, hinduska czy arabska - klasy średniejej ${ }^{24}$ jednocześnie deprecjonuje zawłaszczający dyskurs wytworzony przez europejską burżuazję, w którym racjonalizm, nowoczesność, kapitalizm, a nawet historia, mają świadczyć o zachodniej wyjątkowości, ponieważ, jak twierdzi, ten samozachwyt nie miał oparcia w realnej, materialnej przewadze cywilizacyjnej. Ostatecznie zatem nie odrzuca samego zjawiska - dominacji dzięki przewadze materialnej - a jedynie jego skutki filozoficzne i społeczne.

Zogniskowanie analizy wokół materialnego aspektu renesansu spycha na drugi plan idee. Uznanie formacji intelektualnej za wtórną wobec podstaw ekonomicznych, w szerokim rozumieniu, implikuje jednocześnie pozycję, w jakiej Goody stawia swoją twórczość wobec pozostałych teoretyków renesansu. Jest to skrajne odrzucenie „historii ducha” i wszelkich jej modyfikacji jako wartościowego narzędzia analitycznego. W przypadku tak Renesansu, jak i Kradzieży historii podyktowane jest to sprzeciwem wobec silnych eurocentrycznych predylekcji Geistesgeschichte. Zabieg zamknięcia cech epoki w ramy zjawisk gospodarczych pozwala na powstanie pojęcia „renesansu” jako zjawiska socjologicznego. Takie rozszerzenie rozumienia jest pochodną zabiegów innych badaczy, którzy

${ }^{24}$ Goody odnosił się przede wszystkim do okresu panowania dynastii Qin (221-207 p.n.e.), Tang (618-907 n.e.) oraz Ming (1368-1644), w rozdziale napisanym z Stephenem Fennellem „Renesans w Chinach” (Renesans, s. 255-307). W Kradzieży historii rozważał problem klasy średniej w ramach fragmentów poświęconych feudalizmowi (s. 79-109), zagadnieniu despotyzmu w Imperium Osmańskim (s. 110-136) czy krytycznej analizie książki Wielkie miareczkowanie. Nauka i społeczeństwo w Chinach i na Zachodzie Josepha Needhama (s. 137-165). o fascynacji wartościami i osiągnięciami burżuazji u Marksa pisał Piotr Przybysz, Liberalna koncepcja jednostki a marksizm, w: Marksizm, liberalizm, próby wyjścia, red. L. Nowak, P. Przybysz, Poznań 1997, s. 135-157. 
doszukiwali się renesansu w różnych czasoprzestrzeniach. Przykładami mogą być tutaj choćby renesans karoliński czy renesans XII w. ${ }^{25}$ Goody twierdzi jednak, że dzięki przyjęciu trzech wartości - patrzenia wstecz, sekularyzacji i postępu - jako elementów decydujących o renesansowym charakterze danej epoki, można znaleźć szereg „renesansów” we wszystkich kulturach piśmiennych. Ramy pojęciowe tak pojmowanego zjawiska pękają na tyle, że mianem renesansu można nazwać dziesiątki okresów historycznych, a jednocześnie przestać uznawać renesans „właściwy” za spełniający te warunki.

Oczywiście użycie słowa „renesans” było w historiografii zawłaszczające wobec kultur pozaeuropejskich, zbyt łatwo odrzucano także perspektywę porównawczą. Goody wielokrotnie podkreśla to spostrzeżenie, pisząc, że „uprzywilejowali oni [badacze historii globalnej - K.B.] Zachód w sposób tak przemożny, że pozbawili Wschód należnej mu pozycji w dziejach powszechnych” ${ }^{26}$, a gdzie indziej o „szeroko rozpowszechnionym na Zachodzie poglądzie, nagłośnionym przede wszystkim przez Webera, że europejskie miasta fundamentalnie różnią się od miast na Wschodzie"27. Wyróżnia on w ten sposób generyczny problem zachodniej historiografii, jednocześnie insynuując, że ta kwestia była wcześniej rozpatrywana niedostatecznie. Tymczasem już w 1957 r. Arnold Joseph Toynbee zauważał: „Używając słowa «renesans» jako nazwy własnej pozwoliliśmy sobie na błąd, polegający na postrzeganiu pewnego wydarzenia jako wyjątkowego i niepowtarzalnego fenomenu, podczas gdy w rzeczywistości nie było ono niczym więcej niż jednym szczególnym przypadkiem powracającego w historii zjawiska"28. Goody krytykował Toynbeego za używanie określeń takich jak „naturalna ekspresja zachodniego ducha" 29 w odniesieniu do renesansu, pisząc, że to „esencjalizm w formie najprymitywniejszej" ${ }^{30}$, pominął jednak powyższy fragment. Tak ustawiona krytyka oparta została na doktrynerskim odrzuceniu historii idei jako skutecznej metody opisania zjawiska renesansu oraz nie wprost zwerbalizowanej niechęci do perspektywy kulturowej. Metodologiczne

25 Szerzej patrz: G.W. Trompf, The Idea of Historical Recurrence in Western Thought. From Antiquity to the Reformation, Berkeley 1979; Renaissances Before the Renaissance. Cultural Revivals of Late Antiquity and the Middle Ages, red. W. Treadgold, Stanford 1984.

${ }^{26}$ J. Goody, Kradziez historii, s. 192.

27 Ibidem, s. 227.

28 A.J. Toynbee, A Study of History, t. 9, Oxford 1957, w polskim przekładzie z 2000 r. (skrót i wybór) przegląd renesansów znajduje się w tomie dziesiątym, a podany fragment nie został uwzględniony. Cytat za: P. Burke, Renesans, s. 7.

29 A.J. Toynbee, op. cit., s. 84.

${ }^{30}$ J. Goody, Kradzież historii, s. 334. 
propozycje Burke'a, który próbował analizować renesans gdzieś pomiędzy światem materialnym a ideami ${ }^{31}$, są w pracach Goody'ego całkowicie pominięte, pomimo że Burke nie odrzucał wcale możliwości porównawczego studium cywilizacji. Opierać się ono miało na zasadzie odmiennych perspektyw i wzorców kulturowych, a co najważniejsze działać miało obustronnie pomiędzy cywilizacjami wschodnimi a zachodnią. W artykule poświęconym Goody'emu ${ }^{32}$ Burke, poza uwagami faktograficznymi, generalnie zgadza się co do metody, wywodząc ją zresztą właśnie od Toynbeego. Dobrze zawoalowany sceptycyzm wobec twierdzeń kolegi z Cambridge opierał się w przypadku Burke'a przede wszystkim na obronie autonomiczności (rozumianej jako historyczność) poszczególnych „renesansów”, ze szczególnym uwzględnieniem europejskiego nazywanego w tej dyskusji „the Big One"33.

Goody perspektywę porównawczą widział jednak odmiennie, jako poszukiwanie tożsamych zjawisk, wielkich struktur, które miały znaczyć to samo, bez względu na kontekst. Takie ujęcie tematu miałoby podważyć eurocentryczne spojrzenie na przeszłość, bo wszelkie zjawiska sprowadzone do spłaszczonych makrostruktur nie pozwalają na hierarchizację co do samej ich istoty. Rozwój poszczególnych cywilizacji można przedstawić na wykresie przypominającym drzewka postępu z gier strategicznych. Określone technologie i idee są ściśle zhierarchizowane zdobywanie nowych jest możliwe tylko dzięki pozyskaniu poprzednich, mniej zaawansowanych, a nielinearny, skokowy rozwój prawie w ogóle nie jest możliwy. Na przykład wynalazek druku miałby w takim układzie oznaczać dla każdej cywilizacji to samo, podczas gdy w rzeczywistości wiązał się z zupełnie innymi formami komunikacji, różnymi dla każdej kultury korzystającej z jego dobrodziejstw ${ }^{34}$. Zdobycie innowacji pozwala na awans w hierarchii rywalizujących przeciwników. Dzieje się to jednak za cenę wymazania kulturowej odmienności. Stratyfikacja rozwoju cywilizacji odbywa się tutaj bowiem według arbitralnie narzuconych kategorii, takich jak racjonalna nauka, innowacyjna i świecka sztuka ${ }^{35}$, kapitalizm, nowoczesność, a w warunkach zglobalizowanego świata, także wynikająca z powyższych dominacja.

31 P. Burke, Kultura i społeczeństwo, s. 10-12.

${ }^{32}$ P. Burke, Jack Goody and the Comparative History of Renaissances, „Theory, Culture \& Society" 26, 2009, 7-8, s. 16-31.

33 Ibidem, s. 27-28.

34 Patrz przyp. 21.

35 Goody za znak rozwoju sztuki uważa np. rozwój „świeckiego” tła, powstanie perspektywy i zarzucenie tematów religijnych; J. Goody, Renesans, s. 21, 25, 40-45, 71-72, 102-105, 223. 
Jeśli uznamy za wartościowe twierdzenie Burke'a, że renesans jest rodzajem mitu, w którym fałszywe postrzeganie przeszłości i sposobów odniesienia się do niej (przecenianie tak bliskości odrodzenia do starożytności, jak i jego dystansu od średniowiecza), łączy się z „symbolicznymi opowieściami o bohaterach, którzy są mocno przerysowani" ${ }^{36}$, to okrojenie zjawiska do jego ram „socjologicznych” pozbawia je jednocześnie najważniejszej cechy wyróżniającej. Goody, uważając renesans za historiograficzny mit, nie uznaje jednocześnie konsekwencji tego założenia, próbując uzasadnić istnienie tego zjawiska na poziomie materialnym, poza strukturą samego mitu.

\section{Humanizm i sekularyzacja}

Zwróciłem już uwagę na kilka zjawisk, które Goody uznaje za decydujące przyczyny renesansu lub za fenomeny mu towarzyszące. Chciałbym podjąć próbę skonfrontowania niektórych $\mathrm{z}$ nich z twierdzeniami innych badaczy. Zajmę się tutaj przede wszystkim znaczeniem sekularyzacji i jej relacji do humanizmu, wpływem innowacji na sztukę, narodzinami indywidualizmu oraz rolą sceptycyzmu w powstaniu nowoczesnego dyskursu naukowego. Stosunek Goody'ego do religijności jest niezwykle ważny dla tez zawartych tak w Kradzieży historii, jak i Renesansie. W pierwszej z wymienionych książek autor zauważył, że:

Okres zwany odrodzeniem wielu historyków nazywa też wczesną nowożytnością, który to termin wskazuje raczej na przyszłość i narodziny, niż na przeszłość, śmierć i odrodzenie. To raczej stopień, w jakim wcześniej wiedza, sztuka (a nawet życie rodzinne) były podporządkowane pewnej specyficznej światowej religii, mianowicie chrześcijaństwu, uczynił renesans europejski czymś spektakularnym. Reformacja, która również polegała na zwrocie ku wcześniejszym pismom, oznaczała odrzucenie pewnych ustalonych przekonań i otworzyła możliwość dla takiego samego ruchu w obrębie wiedzy świeckiej. Ograniczyła ona sferę sacrum; także życie rodzinne nie musiało już być podporządkowane regułom Kościoła Katolickiego ${ }^{37}$.

\section{Z kolei w Renesansie pisał:}

Tym, co szczególnie odróżniało Europę, był stopień załamania się dawnej wiedzy, co częściowo miało związek z nadejściem dominującej, monoteistycznej religii, a także z ogromem dziedzictwa starożytnego i obszarów

${ }^{36}$ P. Burke, Renesans, s. 2.

${ }^{37}$ J. Goody, Kradzież historii, s. 142. 
dojrzałych już do odrodzenia z chwilą, gdy ta religia rozluźniała swój uścisk, czyli gdy nastąpiła częściowa sekularyzacja. Zakładanej zwykle przez późniejszą naukę ciągłości ze światem klasycznym nigdy nie było ${ }^{38}$.

Dwa powyższe cytaty oddają w pełni stosunek autora do zagadnienia religii i jej znaczenia dla zjawiska renesansu. Ale czy rzeczywiście postępująca sekularyzacja miała tak ważkie znaczenie dla renesansu? Goody próbował, jak już to widzieliśmy wcześniej, udowodnić, że odrodzenie musi poprzedzić pęknięcie albo przynajmniej rozszczelnienie granicy wyznaczonej przez opresję religijną. Twierdzenie to koresponduje z takimi przekonaniami, jak to, że w historii Chin nigdy nie doszło do tak „spektakularnego odrodzenia”, ponieważ w cywilizacji tej nie było dominującej religii monoteistycznej ${ }^{39}$. Spadek znaczenia religii tak w życiu codziennym, jak i w praktykach badawczych oraz artystycznych stanowił dla Goody'ego tak istotny składnik, że przy przedstawianiu katalogu „renesansów” w innych kulturach, te, które nie były związane z sekularyzacją, traciły na znaczeniu. Omawiając, w napisanym wraz ze Stephenem Fennellem rozdziale "Odrodzenie w świecie islamu” ${ }^{40}$, islamski renesans za Abbasydów, podkreśla, że nie był on pełny, ponieważ, wraz z niechęcią do sztuk przedstawieniowych i świeckiej literatury, nie zanotowano w tym czasie także skłonności sekularyzacyjnych ${ }^{41}$. Dopiero odszukanie wzorców z przeszłości i zrzucenie „okowów dominującej religii”, miały wspólnie stanowić o innowacyjności epoki. Społeczeństwo wieloreligijne i wielokulturowe miało sprzyjać istnieniu rozbudowanej, zsekularyzowanej sfery życia, swobodnej wymianie poglądów oraz postępującej racjonalizacji sposobów postrzegania świata. Czy tego typu zjawiska rzeczywiście towarzyszyły włoskiemu renesansowi, a w szczególności humanizmowi?

William J. Bouwsma w swoim klasycznym tekście The Interpretation of Renaissance Humanism ${ }^{42}$ starał się zestawić wczesne koncepcje na temat źródeł humanizmu, poczynając od Burckhardta. Wyróżnił trzy następujące po sobie tendencje. Pierwsza z nich to optymizm i podkreślanie znaczenia renesansu dla powstania nowoczesnego świata. Głównym przedstawicielem tego nurtu, nazwanego przez Bouwsmę tradycyjnym, obok autora Kultury odrodzenia we Włoszech, miał być Georg Voigt, który mniej więcej w tym samym czasie (1859) opublikował w Berlinie pracę Die Wiederbelebung des Classischen Alterthums, oder das erste Jahrhundert des

\footnotetext{
${ }^{38}$ J. Goody, Renesans, s. 30.

39 Ibidem, s. $258 \mathrm{nn}$.

40 Ibidem, s. 125-187.

41 Ibidem, s. 140-141.

${ }^{42}$ W.J. Bouwsma, The Interpretation of Renaissance Humanism, Berkeley 1959.
} 
Humanismus. Drugi nurt skupiał krytyków tego podejścia, którzy dezawuowali znaczenie renesansowego humanizmu, tak jako początku nowoczesnego świata, jak i ruchu przeciwstawianego średniowieczu. Najważniejszymi wśród nich mieli być Heinrich Thode, Charles Homer Haskins czy Giuseppe Toffanin. Ostatnim rozpoznanym przez Bouwsmę nurtem miał być rewizjonizm. Jego przedstawiciele kontynuowali w pewnym sensie tradycyjne myślenie o renesansie, przy jednoczesnym uwzględnieniu różnorodności idei w jego łonie. Badacze tacy jak Paul Oskar Kristeller, zdający sobie sprawę z druzgocącej krytyki twierdzeń Burckhardta (trzeba przyznać, że często spłaszczającej intencje szwajcarskiego badacza), unikali ogólnoeuropejskiej perspektywy, skupiając się raczej na mniejszych, ograniczonych w czasie i przestrzeni zjawiskach.

Kristeller postulował rozróżnienie pomiędzy „humanizmem” (humanism) a „humanistyką" (the humanities), dowodząc, że pierwsze z tych pojęć, ukute przez dziewiętnastowiecznych uczonych jako określenie filozoficznej orientacji myślicieli renesansu, wywodziło się z drugiego z nich, rozumianego jako ścieżka edukacyjna oparta na kształceniu w zakresie gramatyki, retoryki, historii, poezji czy etyki ${ }^{43}$. Humanistka sprowadzała się do studiowania klasycznych tekstów, a swoim charakterem miała być antytezą ścieżki scholastycznej. Kristeller, doceniając znaczenie średniowiecza dla powstania tego, co współcześnie nazywamy humanizmem, jednocześnie ograniczał na tym przykładzie znaczenie renesansu do powstania pewnego klasycznego wzorca edukacji. Renesansowy humanista miał być tu bardziej „człowiekiem literatury niż człowiekiem idei”" ${ }^{4}$. Zdecydowanie dalej poszedł Konrad Burdach ${ }^{45}$, który uważał, że idea „odradzania, odnawiania i reformy” to koncepcje silnie związane tak z chrześcijaństwem, jak i samym średniowieczem. Ruch renesansowy miał nabrać impetu, jak twierdził, wraz z powstaniem Coli di Rienza w Rzymie w 1347 r. Idąc tym tropem, historycy doszukiwali się źródeł humanizmu w chrześcijańskiej pobożności (Ernst Walser) lub podkreślali silny jego związek z katolicyzmem (Francesco Olgiati). Jednak zdaniem Bouwsmy najbardziej radykalną opinię wobec rzekomych pogańskich czy świeckich źródeł humanizmu przedstawił w latach dwudziestych XX w. wspomniany już wyżej Toffanin ${ }^{46}$. Renesansowy humanista, w jego interpretacji, uznawał wiedzę starożytną za udostępnioną ludzkiemu rozumowi przez Boga i musiała być ona poznawana zgodnie z chrześcijańską

${ }^{43}$ Ibidem, s. 12-13.

${ }^{44}$ Ibidem, s. 13.

45 Ibidem, s. 8.

${ }^{46}$ Bowusma powołuje się na prace G. Toffanina, Che cosa ful'Umanesimo, Firenze 1929; idem, Storia dell'Umanesimo, Bologna 1942. 
wykładnią ${ }^{47}$. W tym ujęciu źródłem myśli odrodzeniowej mieli być przede wszystkim Ojcowie Kościoła, którzy dostarczali „odpoganizowanej" interpretacji klasycznych tekstów. Toffanin uznawał, że humanizm jest ostatecznie reprezentacją chrześcijańskiej idei człowieczeństwa ${ }^{48}$. Jak widać, zagadnienie humanizmu wśród teoretyków renesansu już u podstaw wielkiej dyskusji zapoczątkowanej przez Burckhardta było wiązane z silnymi wpływami chrześcijańskiej myśli średniowiecznej. Wpływy te Goody zdecydowanie podważa, uznając, że nie zostały wystarczająco udowodnione, jednak sam nie podaje przekonujących kontrargumentów. Swoje tezy, oparte na materialistycznej interpretacji, ubiera w formę znanych prawd, pisząc na przykład o świeckości: „Sekularyzm jest uważany za klucz do rozwoju intelektualnego, ponieważ uwalniał on myślenie o wszechświecie od ograniczeń kościelnego dogmatu" ${ }^{49}$. Sekularyzacja ma tłumaczyć odnowienie sztuk i nauki, a te z kolei tłumaczą świeckie tendencje, w ramach funkcjonowania w jednym systemie. Opresja religijna z kolei ma tłumaczyć rzekome niewystępowanie tych tendencji w średniowieczu. Goody przeczy tu jednak poglądom zdecydowanej większości badaczy. Świetny znawca historii Florencji, Gene Brucker, zauważył na przykład, że Kościół prezentował zbyt wpływową siłę, żeby można było go ignorować. Ruchy sprzeciwu wobec instytucji czy antyklerykalizm tłumaczył raczej krytyką kościelnej chciwości czy jednostkowymi przypadkami łamania zasad moralności przez księży ${ }^{50}$, które były uważane za poważny problem także w wiekach wcześniejszych. Zatem w kolebce renesansu, jaką z pewnością była Florencja, nie było mowy o sekularyzmie instytucjonalnym ${ }^{51}$.

47 W.J. Bouwsma, The Interpretation, s. 8-9.

${ }^{48}$ Bouwsma pisał: „Humanism thus represents in the world one set of ideas: Catholic Christianity; that sense of a universal, objective, and rational order which permeated ancient and much of medieval thought; the conception of truth and value as objects to be held in common by all men; internationalism as the ideal of human political community; and the value of Latin as an international language holding men together. Conversely, humanism is eternally opposed to unbelief or Protestantism; to subjectivism, romanticism, and individualism in any form; to scientific naturalism, which ignores the supernatural; to the division of men into particular political communities; and to reliance on the divisive vernacular languages. Toffanin thus attributes very great importance to humanism, and above all to Renaissance humanism as its most advanced expression; but he does so by assigning to it quality almost precisely the opposite of those in the traditional view", ibidem, s. 9.

49 J. Goody, Kradzież historii, s. 254.

50 G. Brucker, Renaissance Florence, New York 1969, s. 180-182.

${ }^{51}$ Brucker zauważa, że we Florencji nigdy nie doszło do przejęcia świeckiej kontroli nad instytucjami Kościoła, jak miało to miejsce w Mediolanie czy Wenecji. Miało być to 
Współcześni badacze rozprawiają się ze stereotypem sekularyzacji bardziej zdecydowanie. Martyna Deszczyńska twierdzi, że:

Teoria sekularyzacji pozostaje więc nadal teorią, i to kwestionowaną przez socjologię. Choć utraciła swą siłę, to ciągle przejawia się w niektórych nurtach historiografii, zwłaszcza w podręcznikach jako element wyjaśniania. Idea sekularyzacji była więc na tyle skuteczna w nauce, że w sposób niezamierzony wpłynęła na jej kształt, poprzez stworzenie właśnie „teorii sekularyzacji". Samo zaś zjawisko zeświecczenia jako element ideologii (teza bez dowodu) nie musiało być prawdziwe, by oddziaływać, choć niekiedy przeczyła temu rzeczywistośćc ${ }^{52}$.

Goody pomijał dwa istotne problemy. Po pierwsze, sekularyzacja na poziomie państwowym czy instytucjonalnym nie musiała się wiązać z dogłębnymi zmianami w stosunku społeczeństwa do religijności. Działo się tak jedynie tam, gdzie zwyciężyła reformacja, która bynajmniej nie charakteryzowała się swobodą myśli czy uwolnieniem jednostki od obowiązku funkcjonowania w ramach wspólnoty wyznaniowej, o czym świadczy zjawisko konfesjonalizacji w krajach niemieckich ${ }^{53}$. Po drugie, ruchy reformy czy odnowy Kościoła wywodziły się z wcześniejszego nurtu devotio moderna, opartego raczej na pobożności niż racjonalizmie. Zatem o dogłębnej sekularyzacji Europy, rozumianej jako złożony proces kulturowy wzmagający modernizację, możemy mówić dopiero od XVIII w..$^{54}$ Co więcej, badacze zwracają uwagę, podobnie jak wcześniej wspominany Burdach, że zjawisko to może być charakterystyczne dla cywilizacji chrześcijańskiej ${ }^{55}$. Potwierdzają to ustalenia socjologa Romana Chymkowskiego, który analizował arabską wiosnę właśnie z perspektywy

pokłosiem uznania gwelfizmu za doktrynę państwową; G. Brucker, op. cit., s. 182; dalej badacz otwarcie krytykuje radykalne interpretacje przemian w renesansowej religijności: „Not innovation, but rather the persistence of traditional forms and attitudes, is the dominant impression gained from an examination of the institutional structure of the Florentine church [--]. Tradition is also the most distinctive feature of Florentine piety in the Renaissance. Some changes did occur in the modes of religious expression, and in the influence of spiritual values upon behavior, but these were not as striking as some historians - following Burckhardt - have suggested, in stressing the worldly, secular orientation of this society", ibidem, s. 202.

${ }^{52}$ M. Deszczyńska, Uwagi o teorii sekularyzacji i sekularyzmie w naukach humanistycznych, KH 122, 2015, 4, s. 749-757, cyt. s. 754.

53 J. Burkhardt, op. cit., s. 5.

${ }^{54}$ M. Deszczyńska, op. cit., s. 752.

${ }^{55}$ K. Lewalski, Sekularyzacja - droga do wypełnienia misji chrześcijaństwa?, KH 122, 2015, 4, s. 799-806. 
zjawisk modernizacyjnych ${ }^{56}$. Zauważył on, że w oczach intelektualistów islamskich (np. Tariqa Ramadana) sekularyzacja, jako proces napędzający modernizację, jest postrzegana jako koncepcja wynikająca z chrześcijańskiej koncepcji czasu. Zatem, jeśli rzeczywiście sekularyzacja jest warunkiem wstępnym wystąpienia renesansu, a jednocześnie jest zjawiskiem typowo zachodnim, teoria Goody'ego staje się nie mniej zawłaszczająca niż krytykowane w jej ramach koncepcje historiograficzne.

\section{Indywidualizm, sztuka i nauka}

Peter Burke, rozważając kulturalne znaczenie renesansu, pisał:

Choć w samych założeniach wskrzeszenie antyku miało być gruntowne i dogłębne, to nie zamierzano zastąpić nim chrześcijaństwa. Jeśli uznamy ten fakt, w oczywisty sposób zamażemy granicę oddzielającą renesans od średniowiecza, ponieważ formy antyczne naśladowano już w poprzedzającej gotyk sztuce „romańskiej”, [--] antycznych poetów zaś, na przykład Wergiliusza i Homera, studiowano w średniowiecznych klasztorach i na uniwersytetach ${ }^{57}$.

Twierdzenie to wprowadza nas w ściśle powiązany z sekularyzacją problem nowatorskości renesansowej sztuki. Goody, mimo swojej dogłębnej krytyki znaczenia renesansu dla powstania nowoczesnego świata, dostrzega przemiany w sztuce, jakie dokonały się pomiędzy XV a XVII w. w kategoriach dynamicznego postępu. Zgodnie z przyjętą perspektywą twierdzi, że rozwój sztuk stymulowała sekularyzacja i rozwój ekonomiczny. Czynniki te miały wyzwolić bardziej wyrafinowane formy artystycznego wyrazu spod religijnej opresji. Jako argument podaje m.in. przykład materialnych warunków funkcjonowania malarzy w średniowieczu. Artyści, posiadający status rzemieślników w przededniu odrodzenia, mieli być pozbawieni „indywidualnej inwencji” jako prości wykonawcy zleceń patrona, czyli najczęściej Kościoła ${ }^{58}$, zmuszeni przez swoich mecenasów do tworzenia jednakowych prac, poruszających niemal wyłącznie tematykę religijną. Goody zwraca jednocześnie uwagę, że „wszelka wyższa sztuka była religijna, nie po prostu dlatego, że Kościół był bardzo ważnym mecenasem, lecz ponieważ tak zadekretowała osadzona w Starym Testamencie ideologia. Albo może dlatego, że etap semickiego

${ }^{56}$ R. Chymkowski, Arabskie Przebudzenie, modernizacja i postkolonializm, „Kultura Współczesna" 2014, 1, s. 46-56.

57 P. Burke, Renesans, s. 30.

${ }^{58}$ J. Goody, Renesans, s. 25. 
anikonizmu dobiegł końca w katolicyzmie, który później zaczął dopuszczać portretowanie nawet samego Najwyższego Boga, a przecież wysoka sztuka dozwalała jedynie na przedstawienia religijne" 59 . Nie do końca zrozumiałe jest zatem, dlaczego sekularyzacja, tak jako otwarcie na nowe tematy, jak i zmiana źródeł finansowania sztuki, miałaby według Goody'ego stać się motorem napędowym przemian. Kłóci się to twierdzenie z materialnymi warunkami pracy malarzy renesansowych, którzy dalej malowali portrety na zamówienie bogatych patronów, tylko tym razem częściej świeckich ${ }^{60}$. Co więcej, jak Goody sam zauważył, „koniec semickiego anikonizmu" dokonał się w ramach konserwatywnej religii monoteistycznej, jaką bezsprzecznie był rzymski katolicyzm.

Innym istotnym zagadnieniem renesansowej sztuki, jakie podjął Goody, był problem innowacji. Nowatorskość sztuki renesansowej umieścił on ponownie na linii postępu, wedle której sztuka odrodzenia była bardziej wyrafinowana i lepsza od sztuki średniowiecza. Określenie poziomu wyszukania sztuki z perspektywy zastosowanych technik bądź stopnia naturalizmu jest sposobem wpisania zjawiska w wielką narrację o odradzaniu się europejskiej kultury. Jednakże wprowadzenie nowych metod (albo ich odnowienie) ani nie musi być postrzegane w kategoriach postępu, ani mieć bezpośrednich źródeł w sztuce antycznej. Wspomnę tylko na marginesie tych rozważań, że także na tym polu istnieli badacze, którzy doszukiwali się źródeł realizmu we wzorcach średniowiecznych ${ }^{61}$.

Kluczowa zdaje się tutaj koncepcja imitacji. Wizja odnowy sztuk opierała się przede wszystkim na próbie odrodzenia wzorców starożytnych, szczególnie rzymskich. Wybitny historyk sztuki i znawca renesansu ErnstH.Gombrich, pisząc o postulatach Filippa Brunelleschiego, zauważył, że były one

równoczesne z reformami humanistów, skupione jednak bardziej na wykorzenieniu złych praktyk niż na wprowadzeniu całkowicie nowych form. Zadziwia, że środki wyrazu architektury quattroccenta mają charakter mniej klasyczny, bliższe są raczej średniowiecznej tradycji. [--] [Był to - K.B.] rodzaj pewnej kontynuacji tradycji, którą tak często odnajdujemy, analizując wytwory renesansu [wyróżnienie - K.B.]. Nic więc dziwnego, że opinie są tak skrajne, odpowiadają przecież różnym poziomom

59 Ibidem, s. 102.

${ }^{60}$ Peter Burke uważa, że w statusie artysty niewiele się zmieniło. Malarze dalej byli postrzegani jako rzemieślnicy, przeciwko protestowali tacy giganci renesansu jak Leonardo da Vinci czy Giorgio Vasari. Jedyną zmianą było rozszerzenie bazy mecenasów o coraz większą grupę osób świeckich. Patrz: P. Burke, Renesans, s. 14.

${ }^{61}$ Heinrich Thode $n p$. widział w renesansowym sposobie przedstawiania człowieka i natury wpływy franciszkańskie, idem, Franz von Assisi und die Anfänge der Kunst der Renaissance in Italien, Berlin 1885. 
nowatorstwa, które chcielibyśmy przypisać danemu okresowi. Czyż nie jest prawdą, że nowatorstwo leży często w unikaniu błędów naruszających klasyczne normy? Owo unikanie z kolei wpływa z nabytego prawa do krytyki tradycji i odrzucania wszystkiego, co wydaje się zbrodnią i świętokradztwem w oczach starożytnych autorytetów ${ }^{62}$.

W spostrzeżeniu tym ponownie uwidaczniają się dwa odrębne źródła idei renesansu. Nowatorstwo może wynikać z zapatrzenia w dawną tradycję. Imitacja wielkich mistrzów starożytności ma być drogą, na końcu której artystom uda się prześcignąć autorytety. Jednak punktem wyjścia jest właśnie spojrzenie wstecz ${ }^{63}$. Nowe trendy mogły być także wynikiem błędnego odczytania wzorców antycznych, nieumyślnego - przez brak właściwych źródeł, lub celowego - ze względu na indywidualne predyspozycje artystyczne ${ }^{64}$. W przypadku architektury artyści kierowali się także funkcjonalnością projektowanych budynków, co często odbywało się za cenę precyzyjności oddania antycznego wzorca ${ }^{65}$. Większość tych koncepcji powstało w ramach wąskiej grupy entuzjastów, prowadzących spory nad czystością doktryny, którzy ostatecznie nie mieli pojęcia o swoim finalnym celu.

Postrzeganie tego typu zjawisk w kategoriach postępu, a nie po prostu zmiany konwencji, wydaje się być kłopotliwe. Zdaje się zresztą, że Goody jest w swoich twierdzeniach niekonsekwentny. Krytykując, w moim przekonaniu zresztą słusznie, ideę powstania indywidualizmu w renesansie, dostrzega jego dominujące znaczenie dla sztuki. Problem indywidualizmu i jego znaczenia dla odrodzenia jest jednak dużo bardziej skomplikowany. Aron Guriewicz rozważał, czy formy budowania własnej osobowości na wzorcach zaczerpniętych z mirakulów, rycerskich romansów czy od antycznych bohaterów były jedynie prostym naśladownictwem. Twierdził, że tak w średniowieczu, jak i renesansie człowiek dokonywał raczej "autodefinicji przez upodobnienie" do wzorców uznawanych w danym momencie za pożądane ${ }^{66}$. Człowiek średniowiecza różnił się od człowieka renesansu przede wszystkim „odmiennymi formami samopoznania" 67 , a nie poddającym się hierarchizacji rozwojem zdolności do postrzegania

${ }^{62}$ E.H. Gombrich, Od odrodzenia litery do reformy sztuk. Niccolo Niccoli i Filippo Brunelleschi, w: idem, Pisma o sztuce i kulturze, wyb. i oprac. R. Woodfield, Kraków 2011, s. 426. Wyd. oryg. The Essential Gombrich, London 1996.

${ }^{63}$ P. Burke, Renesans, s. 22-23.

${ }^{64}$ Ibidem, s. 14-15.

${ }^{65}$ W taki sposób Gombrich tłumaczył innowacje architektoniczne Brunelleschiego z zastosowaniem perspektywy. Patrz: E.H. Gombrich, op. cit., s. 429-431.

${ }^{66}$ A. Guriewicz, Jednostka w dziejach Europy (średniowiecze), Gdańsk 2002, s. 97.

${ }^{67}$ Ibidem, s. 201-202. 
własnego „ja”. Imitacja, rozważana przez Gombricha, jest właśnie tym pojęciem przybliżającym wielkich artystów XV i XVI w. raczej do ludzi średniowiecza, niż do współczesnych indywidualistów. Czerpanie wzorców z przeszłości, z tekstów, często niepoddanych skrupulatnej krytyce i przyjętych za pewnik, zdaje się być cechą ówczesnej kultury europejskiej.

Prezentowane w książkach Goody'ego opinie na temat religii oraz relacji renesansu do średniowiecza znajdują także swoje odzwierciedlenie $\mathrm{w}$ jego stosunku do rodzącej się nauki i jej znaczenia. W obu analizowanych tutaj książkach autor poświęcił sporo miejsca naukom przyrodniczym i medycynie, a także technice rozwijającej się, jak twierdził, niemal w symbiozie z gospodarczą koniunkturą. W Kradzieży historii możemy przeczytać:

Zacofanie zachodniej nauki - które pozwalało na swobodę rozwoju - wynikało, moim zdaniem, w większej części z dominacji chrześcijaństwa i jego światopoglądu. Potencjał ten został uwolniony, przynajmniej częściowo, przez nurty myśli renesansowej, dzięki zwrotowi ku wzorcom rzymskim i greckim, które nie były podporządkowane żadnej światowej religii. Sekularyzacja znacznych obszarów wiedzy, wspomagana przez druk, krytycyzm reformacyjny i rozwój szkolnictwa, uniwersytetów i humanizmu, prawdopodobnie przyczyniła się do tych przemian, podobnie jak rozwój handlu, odkrycia zamorskie oraz cała seria wydarzeń, które wspierały badania i wzrost kapitalizmu ${ }^{68}$.

Ponownie zatem sekularyzm staje się głównym motorem napędowym przemian. Oczywiście, zastrzeżenie, że humaniści wcale nie odrzucili Boga, łagodzi tylko wydźwięk tej konstatacji, ale w praktyce niewiele zmienia. Dalej bowiem języczkiem u wagi jest przestrzeń, jaką zajmuje sfera sacrum w życiu renesansowego człowieka.

Badania monograficzne ponownie stawiają te twierdzenia pod znakiem zapytania. Organizacja edukacji prawdopodobnie wcale nie uległa tak daleko idącej sekularyzacji, jak chciałby tego Goody, a rewolucja naukowa miała zdecydowanie bardziej skomplikowane przyczyny. Przykładami współistnienia religii i nowych koncepcji mogą być szkoły jezuickie, które w drugiej połowie XVI w. oparły swój program edukacyjny na wzorcach klasycznych. Jak zauważył Burke, proces ten przebiegał inaczej niż wcześniejsze próby Erazma z Rotterdamu, który chciał pogodzić chrześcijaństwo z tradycją antyczną, lecz różnice te obserwowalne były jedynie w szczegółach ${ }^{69}$.

\footnotetext{
${ }^{68}$ J. Goody, Kradzież historii, s. 162.
}

${ }^{69}$ P. Burke, Renesans, s. 56. 
Należy tutaj pamiętać, że przewrót naukowy jest związany raczej z końcem, niż początkiem renesansu. Przemiany w myśleniu o świecie natury przypadły na koniec wieku XVI i początek XVII, dlatego też bezpośredni wpływ włoskiego renesansu na te zjawiska bywał nadinterpretowywany. Wskazują na to badania Bouwsmy, który podjął ten problem w książce Waning of the Renaissance ${ }^{70}$. Podważał ciągłość rozwojową między wczesnorenesansowym odkrywaniem i odradzaniem wiedzy starożytnych, a późniejszym powstaniem racjonalizmu i sceptycyzmu, w których poszukiwał z kolei dialektycznej syntezy z wielowymiarowego zbioru idei, zjawisk i kierunków. Ścierać się miały renesansowa tendencja do kreatywnej wolności z naturalnym dążeniem do porządku. Co prawda Bouwsma uznawał, że wynikiem tego procesu jest zmiana podejścia, która jednak nigdy nie zaburzyła dualizmu ludzkiej natury, dążącej jednocześnie do porządku i do spontanicznej kreatywności ${ }^{71}$. Obrazowo to zjawisko opisał już Clive Staple Lewis, który zauważył, że oskarżenie Galileusza nie wynikało z wyników obserwacji bardziej szokujących, niż te zaprezentowane wcześniej przez Kopernika, ale z jego założenia, że heliocentryczny model wszechświata jest bezdyskusyjnie prawdziwy, kiedy pierwotnie była to jedna $\mathrm{z}$ wielu teorii ${ }^{72}$.

Bouwsma zwracał uwagę, że główną zmianą, jaka nastąpiła w stosunku do wiedzy starożytnej w renesansie, było dostrzeżenie w niej przeciwstawnych nurtów. W związku z powyższym dawna, mająca swą genezę w średniowieczu, idealizacja myśli antycznej zastąpiona została wraz z końcem epoki indywidualizacją dociekań poszczególnych bada$\mathrm{czy}^{73}$. Mieli oni sympatyzować bądź z poszczególnymi szkołami filozofii, bądź nawet całkowicie odrzucać autorytet starożytnych ${ }^{74}$. W takich warunkach rodził się właśnie nowożytny racjonalizm i sceptycyzm, gdzie negacja wzorców antycznych szła w parze z podważaniem scholastyki i modelu arystotelesowskiego (bronionego przez uniwersyteckich tradycjonalistów $\left.{ }^{75}\right)$.

70 Tytuł książki odnosi nas do jednej z głównych inspiracji Bouwsmy, czyli do Jesieni średniowiecza Johanna Huizingi. Podobnie jak wielki holenderski badacz, skupił się w niej na różnych, często odmiennych prądach w myśleniu, które wpływały na nasz obraz epoki. Patrz: W.J. Bouwsma, The Waning of the Renaissance, 1550-1640, New Heaven 2002.

71 Ibidem, s. 259-260.

72 C.S. Lewis, Odrzucony obraz. Wprowadzenie do literatury średniowiecznej i renesansowej, Kraków 1995 (oryg. ang. 1964), s. 24.

73 W.J. Bouwsma, The Waning, s. 35-36.

${ }^{74}$ Przeciwko uniwersalizacji własnej percepcji świata opowiadał się zdecydowanie Montaigne, ibidem, s. 41; z kolei zanegowanie starożytnych wzorców stało się podstawą twierdzeń tak Francisa Bacona, jak i Kartezjusza, ibidem, s. 38.

${ }^{75}$ Ibidem, s. 11. 
Wielu badaczy wskazuje, że sekularyzacja nie tylko nie miała wpływu na rozwój nauk, ale także nie musiała być tego rozwoju skutkiem. U podstaw rozszerzenia wiedzy stała międzykulturowa komunikacja, szczególnie w okresie jej zintensyfikowania w dobie wielkich odkryć. Harold J. Cook, we wstępie do swojej pracy o transferze wiedzy w holenderskim imperium kolonialnym, wskazuje, że przemiana nie nastąpiła „w bibliotece”, a właśnie „na okrętach"76. Wiedza ta była przejmowana ze względu na swoją praktykę, a nie antyczne czy chrześcijańskie idee, i dopiero z czasem była poddawana interpretacji akademickiej. Same podróże zaś, wbrew utartym przekonaniom o poszerzaniu dzięki nim horyzontów myślowych, nie musiały wzmagać sekularyzacji. Nastrój tych zjawisk Bouwsma określał jako wielki religijny optymizm, wyrażany w zapale chrystianizacyjnym, a nie tryumfie świeckiej tolerancji ${ }^{77}$.

Problem zatem jest zdecydowanie bardziej złożony. Ruch, jakim był renesans, był skrajnie niejednorodny i łączył w sobie nurty względem siebie antagonistyczne. Dlatego też tak jednoznaczne opowiedzenie się za spójną wizją odrodzenia musi budzić kontrowersje. Ciekawy jest fakt, że Goody, podważając z jednej strony znaczenie renesansu w skali globalnej (zauważając wpływy wschodnie na kulturę europejską, jak i wschodnią zdolność do odradzania własnej kultury), nie odrzuca jednak tradycyjnej narracji modernizacji i postępu.

\section{Uniwersalizm ludzkich wartości a różnorodność kulturowa}

Rozwiązaniem problemów historii globalnej, jakie proponuje Goody, jest skrajne odrzucenie wyjątkowości zjawisk, a w zamian podkreślenie wspólnych cech kultur piśmiennych. Ujęcie takie jednak generuje dwa poważne problemy. Po pierwsze, odbiera prawo poszczególnych kultur do różnorodności, podporządkowując je dążeniu do postępu. Po drugie, arbitralnie ustanawia kategorie, w jakich te kultury mają być porównywane. Już sam cel dążenia - postęp - ma być pozytywną wartością, określoną i ocenianą w ramach instytucji „obiektywnej wiedzy”. Pod tym określeniem jednak kryją się eurocentryczne wartości, uznawane współcześnie przez świat zachodni za uniwersalne.

${ }^{76}$ H.J. Cook, Matters of Exchange. Commerce, Medicine, and Science in the Dutch Golden Age, New Haven 2007, s. 2-5.

77 W.J. Bouwsma, The Waning, s. 112. 
W podobnym duchu przebiegała gorąca dyskusja pomiędzy Gananathem Obeyesekere a Marshallem Sahlinsem dotycząca konsekwencji, jakie niosła za sobą teza Sahlinsa o deifikacji kapitana Jamesa Cooka przez Hawajczyków ${ }^{78}$. Postrzeganie brytyjskiego odkrywcy jako jednej z emanacji bóstwa Lono, wypływające ze zbieżności dat wizyt Cooka na pacyficznym archipelagu z obchodzonym przez tubylców świętem Makahiki, miało doprowadzić do jego śmierci. Zdecydowaną krytykę tych twierdzeń przeprowadził Obeyesekere ${ }^{79}$, zarzucając Sahlinsowi etnocentryzm i porównując jego twierdzenie ze słynnym mitem, wedle którego mieszkańcy dzisiejszego Meksyku uznali Hernána Cortésa i hiszpańskich konkwistadorów za istoty boskie. Rzekoma deifikacja, której fundamentem miała być biel skóry przybyszów, stała się wzorcem narracyjnym dla zachodnich opowieści o nowożytnych kontaktach międzykulturowych, a z czasem podstawą rasistowskiej ideologii europejskiego kolonializmu. Sahlins odpowiedział na te zarzuty ką́śliwą polemiką ${ }^{80}$, zarzucając swojemu oponentowi, że tworzy całkowicie wyimaginowaną wspólnotę „tubylców”, poddanych opresji Zachodu ${ }^{81}$. Wspólnota ta, opierając swoją tożsamość na doświadczeniu kolonializmu, miałaby domagać się praw do wartości zawłaszczonych przez Europejczyków, przede wszystkim racjonalizmu. Jednocześnie, jak zauważył Sahlins, Obeyesekere nie dostrzegł pewnego zagrożenia, związanego z tymi wartościami: „Zdroworozsądkowy realizm burżuazyjny, gdy potraktować go jako koncept historiograficzny, stanowi rodzaj przemocy symbolicznej [wyróżnienie - K.B.] wobec innych czasów i obyczajów. Przekonuję, że nie można z powodzeniem uprawiać historii, nawet historii współczesnej, bez uwzględnienia idei, działań i ontologii, które nie są i nigdy nie były nasze. Różne kultury, różne racjonalności" 82 .

Sahlins stwierdził zatem, że doszukiwanie się uniwersalnej (w domyśle - europejskiej) racjonalności we wszystkich kulturach, jako cechy charakteryzującej wszystkie istoty ludzkie, jest nie tylko działaniem arbitralnym i wykluczającym, ale także wartościującym zachodni model rozwoju społeczeństwa jednoznacznie pozytywnie. Czy w takim ujęciu

${ }^{78}$ Twierdzenie to można znaleźć w kilku pracach autorstwa Marshalla Sahlinsa. Polskiemu czytelnikowi najłatwiej dotrzeć do tłumaczenia: M. Sahlins, Wyspy historii, Kraków 2006 (oryg. ang. 1976).

${ }^{79}$ G. Obeyesekere, The Apotheosis of Captain Cook. European Mythmaking in the Pacific, New Jersey 1997.

${ }^{80}$ Odpowiedź ta została wydana w formie książki: M. Sahlins, Jak myśla „tubylcy”. O kapitanie Cooku, na przykład, Kraków 2007 (oryg. ang. 2006).

81 Obeyesekere jest amerykańskim antropologiem pochodzącym ze Sri Lanki.

${ }^{82}$ M. Sahlins, Jak myśla „tubylcy”, s. 23. 
nieodnalezienie pewnych zjawisk wysoce wartościowanych przez cywilizację zachodnią automatycznie odbiera prawo do bycia cywilizacją?

Tendencja do zacierania granic międzykulturowych i skrajnego spłaszczania różnic jest silnie widoczna w pracach Goody’ego. Pisząc, że „jednym z najbardziej szkodliwych mitów Zachodu jest to, że wartość naszej «judeochrześcijańskiej» cywilizacji należy odróżnić od wartości Wschodu w ogóle, a zwłaszcza islamu"83, nie dostrzegł paradoksu, w którym pozorne odrzucenie etnocentryzmu i włączenie cywilizacji islamskiej i dalekowschodnich do zachodniego procesu historycznego staje się narzędziem wykluczenia. Dzieje się tak z dwóch powodów. Po pierwsze, wyklucza się z tego dyskursu kultury niepiśmienne, które nie przeszły rewolucji epoki brązu, nie posiadają „wysoko rozwiniętego rolnictwa”, ani „kultury miejskiej” w naszym rozumieniu. W tym przypadku, mimo że autor nie pisze tego wprost, a być może wcale tak nie myśli, można odnieść wrażenie, że kultury te po prostu są gorsze. Po drugie zaś, poprzez narzucenie kategorii przez Zachód zawłaszczonych i zreinterpretowanych oraz ignorowanie innych historiografii niż zachodnia wyklucza tych, którzy mają zostać „równouprawnieni”. Tak Renesans, jak i Kradzież historii są właściwie o Europie. Wartości świata zachodniego są u Goody'ego jedynym punktem odniesienia dla innych kultur, co zdradza bibliografia jego prac: prawie wyłącznie zachodnia ${ }^{84}$. Tak szeroko zakrojone ujęcie porównawcze wyklucza dogłębne badania, jednak w moim przekonaniu samo porównywanie zjawisk bez prób analizy ich znaczenia, a często bez zrozumienia ich wyjątkowości, staje się jałowe. W praktyce, „inny”, który ma zostać równouprawniony, zostaje pozbawiony głosu. Na marginesie tych rozważań pozostaje niedostrzeżone przez Goody'ego zawłaszczenia wartości przez Zachód także w stosunku do Europy Środkowo-Wschodniej.

Sprzeciw Goody'ego wobec etnocentryzmu jest tylko powierzchowny, nie odrzucił on bowiem ani idei postępu, ani imperializmu. Problem może polegać właśnie na obraniu określonej perspektywy, tak zresztą częstej w próbach ujęć historii globalnej. Jak twierdzi Jan Swianiewicz w książce

${ }^{83}$ J. Goody, Kradzież historii, s. 252.

${ }^{84}$ Goody niemal całkowicie ignoruje historiografię powstałą poza granicami „zachodniego świata akademickiego". Przykładem jest dość krótka lista chińskich badaczy. Cytuje albo odnosi się do badań K.C. Chang (Food in Chinese Culture - Anthropological and Historical Perspectives, New Haven 1977), Ching-Tzu Wu (The Scholars, Beijing 1973), Ho Ping-ti (The Ladder of Success in Imperial China. Aspects of Social Nobility, 1368-1911, New York 1962) czy Chan W.K.K. (Merchants, Mandarins, and Modern Enterprise in late Ch'ing China, Cambridge 1977). Znamienne jest to, że poza Ching-Tzu Wu wszyscy kształcili się i pracowali na uczelniach anglosaskich. Patrz: J. Goody, Kradzież historii, s. 212-213. 
Możliwość makrohistorii ${ }^{85}$, różne problemy wynikające z poszczególnych opracowań makrohistorycznych (czy też historii globalnych i totalnych) „prowadzą do siebie nawzajem, ale w sposób nierozerwalny wiążą się tylko wówczas, gdy tematem badań i historycznej narracji uczyni się kapitalizm" ${ }^{86}$. Nie chciałbym w tym miejscu rozstrzygać o słuszności tego twierdzenia, niemniej jednak Goody, opierając swoje wywody o kategorię kapitalizmu utożsamianego z nowoczesnością, wpadł w pułapkę wpisaną w perspektywę makrohistoryczną. Nie zauważył bowiem, że źródło eurocentrycznej orientacji historiografii może leżeć u podstaw poddziedziny, jaką jest historia pisana z perspektywy globalnej, we wszelkich swoich wariacjach. Chcąc stworzyć uniwersalny i inkluzywny model „nowoczesności” i „kapitalizmu”, przystający do różnych czasoprzestrzeni, konieczne jest ich zdekontekstualizowanie, wyabstrahowanie od warunków historycznych. Uznając pewne zjawiska za socjologiczne, celowo czyni je ahistorycznymi, ponieważ historia w jego przekonaniu jest narzędziem zachodniej opresji. $W$ ten sposób pozbawia je całego tła i warunków stwarzających możliwość ich zaistnienia, sprowadza je do teleologicznych w swym charakterze argumentów w dyskusji o nowoczesności.

Bohaterami dzieł Goody'ego są wielkie cywilizacje, postrzegane jako wzajemnie wpływające na siebie organizmy. Taki wybór aktorów historii niesie za sobą konsekwencje, które w moim przekonaniu znacznie osłabiają argumenty krytyczne wobec etnocentrycznej historiografii zachodniej. Susan Buck-Morss zwróciła uwagę na zasadniczą rolę doboru bohaterów: „Kto - czy też co - jest zbiorowym przedmiotem historii? Czy jest to naród? Cywilizacja? Klasa? A może przebiegły heglowski aktor, rozum? Każda z tych kategorii, nadając konkretne znaczenia aktualnym zjawiskom, jest zarazem pełna rezyduów przeszłości - zawiera w sobie osad historii utopijnych marzeń i kulturowych ślepych plamek, walki politycznej i skutków działania władzy"87.

I właśnie - Goody, uwiedziony „rezyduami przeszłości”, zamiast oddawać głos pomijanemu dotychczas ,innemu”, przemawiał protekcjonalnie za niego. Głos ten powstał w bezpośredniej relacji z zachodnim dyskursem dominacji - stara się mu zaprzeczyć, ale bez niego nie mógłby funkcjonować.

${ }^{85}$ J. Swianiewicz, Możliwość makrohistorii. Braudel, Wallerstein, Deleuze, Warszawa 2014.

${ }^{86}$ Ibidem, s. 458. Swianiewicz poświęca temu zagadnieniu trzy części (s. 305-452) swojej książki, w której analizuje pojęcie kapitalizmu w ujęciu kolejno Fernanda Braudela, Immanuela Wallersteina oraz Gilles'a Deleuze'a i Félixa Guattariego.

87 S. Buck-Morss, Hegel, Haiti i historia uniwersalna, Warszawa 2014 (oryg. niem. 2011), s. 125. 
W jaki zatem sposób mówić o sprawach globalnych? Jakiego narzędzia użyć, by uniknąć szeroko opisanych w tym tekście problemów? Wybrnięcie z impasu utrudniają oddzielające poszczególne dziedziny bariery metodologiczne i konceptualne. Mottem niniejszego tekstu mogłoby stać się zdanie autorstwa Buck-Morss na temat dyskusji wokół Jeana-Jacques'a Rousseau:

Współczesny historyk idei, osądzający Rousseau w kontekście historycznym, spełni swoją zawodową powinność, relatywizując sytuację i oceniając (oraz usprawiedliwiając) rasizm francuskiego myśliciela moralnością jego czasów - a wszystko po to, by uniknąć błędu anachronizmu. Podobnie postąpi współczesny filozof, który, wyćwiczony w analizowaniu teorii całkowicie w oderwaniu od kontekstu historycznego, przypisze pismom Rousseau uniwersalność wykraczając poza intencje samego autora i jego osobiste ograniczenia - po to, by uniknąć w ten sposób błędu redukcji ad hominem ${ }^{88}$.

Fragment ten odnosi się do zasadniczych trudności analitycznych, z jakimi mierzył się w swojej twórczości zarówno Jack Goody (jako „współczesny filozof”), jak i ci, których krytykował („,historycy idei”). Propozycją Buck-Morss jest powrót do ulepszonej koncepcji historii uniwersalnej. Badaczka, nie bez gorącego zaangażowania, promuje takie rozwiązanie jako równouprawniające z jednej, ale niepozbawiające wyjątkowości i prawa do innego postrzegania procesu dziejowego z drugiej strony.

Oto definicja historii uniwersalnej, która zaczyna się tu wyłaniać: ludzka uniwersalność pojawia się nie tam, gdzie wielu różnym kulturom przyznaje się równe prawa, a jednostki postrzega się jako część ludzkości poprzez zapośredniczenie zbiorowych, kulturowych tożsamości, ale w miejscu rozpęknięcia się wydarzenia historycznego. To właśnie w owych nieciągłościach historii ludzie, których kulturę nadwyrężono niemal do kresu jej wytrzymałości, dają wyraz człowieczeństwu wykraczającemu poza ograniczenia kulturowe. I tylko dzięki empatycznemu utożsamieniu z tym surowym, wolnym i delikatnym stanem mamy szansę zrozumieć to, co mówią. Wspólne człowieczeństwo istnieje pomimo wielości kultur i dzielących je różnic. Nietożsamość danej osoby ze zbiorowością pozwala na sekretną solidarność, która ma szansę przemówić do uniwersalnej wrażliwości moralnej, będącej dziś źródłem entuzjazmu i nadziei. Świadomość wspólnego człowieczeństwa rodzi się nie poprzez kulturę, ale poprzez zagrożenie jej zdrady ${ }^{89}$.

88 Ibidem, s. 45.

89 Ibidem, s. 150. 
Podobne twierdzenie sformułował Hamid Dabashi ${ }^{90}$, który w takiej wspólnotowości, opartej na ogólnoludzkich wartościach oraz uniwersalnym ,języku emancypacji”, doszukiwał się szans wyjścia z postkolonialnej zależności. Jeśliby zastosować tę koncepcję jako wartościowe narzędzie analityczne, niewykluczone, że mogłaby dać obiecujące wyniki, choć raczej poza dziedziną historii globalnej, która zdaje się być skazana na operowanie krzywdzącymi uproszczeniami.

\section{Streszczenie}

Brytyjski antropolog sir Jack Goody przedstawił teorię dotyczącą zdolności każdej kultury piśmiennej do odradzania się. Podważył jednocześnie pogląd o wyjątkowości europejskiego renesansu XV-XVI w. Jak twierdził, takie ujęcie tematu pozwala na rozbicie zastałego przekonania o uprzywilejowanej pozycji Europy na drodze do nowoczesności i kapitalizmu. Przyglądając się bliżej używanym przez Goody'ego pojęciom, takim jak sekularyzacja, humanizm, imitacja, indywidualizm i w końcu sam renesans, poddałem krytycznej analizie twierdzenia, zestawiając je z innymi teoriami na temat renesansu oraz sprawdzając ich wewnętrzną spójność. Dekonstrukcja tych założeń ujawniła nie tylko ich wewnętrzną niekoherentność, ale także - paradoksalnie - zagrożenie kryjące się w porównawczych studiach nad cywilizacjami w perspektywie długiego trwania. Twierdzę, że historia globalna, nawet gdy wychodzi z inkluzywnych pozycji i stara się operować równościowym językiem, pozostaje etno-, a właściwie eurocentryczna, dopóki opiera się na wartościach wytworzonych, uznanych i stosowanych w świecie zachodniej nauki, tj. zachodnim racjonalizmie, obiektywizmie, ewolucjonizmie, modernizmie itd.

\section{Ethnocentrism, the One or the Many? A Critical Analysis of Jack Goody's Theory of Renaissances}

The British anthropologist Sir Jack Goody has put forward a theory about the ability of any literary culture to revive. At the same time, however, he questioned the opinion of the uniqueness of the European Renaissance of the fifteenth and sixteenth centuries. As he claimed, such an approach allows us to break down the existing conviction about Europe's privileged position on the road to modernity and capitalism. Looking more closely at the terms used by Goody such as secularization, humanism, imitation, individualism and, finally the Renaissance itself, this text critically analyses his theories, comparing them with some others about the Renaissance, and checking their internal consistency. The deconstruction of these assumptions revealed not only their incoherence, but also - paradoxically - the threat hidden in comparative studies of civilizations in the perspective of long

${ }^{90}$ H. Dabashi, The Arab Spring. The End of Postcolonialism, London 2012. 
duration. It is argued that global history, even when it comes out of inclusive positions and tries to operate with an equitable language, remains ethno- or rather Eurocentric, as long as it is based on the values created, recognised and applied in the world of Western science, that is, Western rationalism, objectivity, evolutionism, modernism, and so on.

Translated by Grażyna Waluga

\section{Bibliografia}

Bouwsma William J., The Interpretation of Renaissance Humanism, Service Center for Teachers of History, Washington 1959.

Bouwsma William J., The Waning of the Renaissance, 1550-1640, Yale University Press, New Heaven 2002.

Braudel Fernand, Kultura materialna, gospodarka i kapitalizm XV-XVIII wiek, t. 1-3, red. nauk. Jacek Kochanowicz, PIW, Warszawa 1992.

Brotton Jerry, The Renaissance Bazaar. From the Silk Road to Michelangelo, Oxford University Press, Oxford 2002.

Brucker Gene, Renaissance Florence, Wiley, New York 1969.

Buck-Morss Susan, Hegel, Haiti i historia uniwersalna, Wydawnictwo Krytyki Politycznej, Warszawa 2014.

Burckhardt Jacob, Kultura odrodzenia we Włoszech. Próba ujęcia, PIW, Warszawa 1991. Burke Peter, Renesans, Wydawnictwo UJ, Kraków 2009.

Burke Peter, Kultura i społeczeństwo w renesansowych Włoszech, PIW, Warszawa 1991. Burke Peter, Jack Goody and the Comparative History of Renaissances, „Theory, Culture \& Society" 26, 2009, 7-8, s. 16-31.

Burkhardt Johannes, Stulecie reformacji w Niemczech (1517-1617). Między rewolucja medialna a przełomem instytucjonalnym, Wiedza Powszechna, Warszawa 2009.

Chymkowski Roman, Arabskie Przebudzenie, modernizacja i postkolonializm, „Kultura Współczesna" 2014, 1, s. 46-56.

Cook Harold J., Matters of Exchange. Commerce, Medicine, and Science in the Dutch Golden Age, Yale University Press, New Haven 2007.

Dabashi Hamid, The Arab Spring. The End of Postcolonialism, Zed Books, London 2012.

Deszczyńska Martyna, Uwagi o teorii sekularyzacji i sekularyzmie w naukach humanistycznych, KH 122, 2015, 4, s. 749-757.

Giesecke Michael, Der Buchdruck in der frühen Neuzeit. Eine historische Fallstudie über die Durchsetzung neuer Informations- und Kommunikationstechnologien, Suhrkamp Verlag, Frankfurt am Main 1994.

Gombrich Ernst H., Od odrodzenia litery do reformy sztuk. Niccolò Niccoli i Filippo Brunelleschi, w: idem, Pisma o sztuce i kulturze, wyb. i oprac. Richard Woodfield, Universitas, Kraków 2011, s. 411-435.

Goody Jack, Literacy in Traditional Societies, Cambridge University Press, Cambridge 1968.

Goody Jack, Economy and Feudalism in Africa, „Economic History Review” 22, 1969, 3, s. 393-405. 
Goody Jack, Technology, Tradition, and the State in Africa, Oxford University Press, London 1974.

Goody Jack, Renesans czy tylko jeden?, Czytelnik, Warszawa 2012.

Goody Jack, Kradzież historii, PWN, Warszawa 2009.

Goody Jack, Capitalism and Modernity. The Great Debate, Polity, Cambridge 2004.

Guriewicz Aron, Jednostka w dziejach Europy (średniowiecze), Marabut, Gdańsk 2002.

Lewalski Krzysztof, Sekularyzacja - droga do wypetnienia misji chrześcijaństwa?,

KH 122, 2015, 4, s. 799-806.

Lewis Clive Staple, Odrzucony obraz. Wprowadzenie do literatury średniowiecznej i renesansowej, Wydawnictwo Znak, Kraków 1995.

Lughod Janet Abu, Europa na peryferiach. Średniowieczny system-świat w latach 12501350, Marek Derewiecki, Kęty 2012.

Obeyesekere Gananath, The Apotheosis of Captain Cook. European Mythmaking in the Pacific, Princeton University Press, New Jersey 1997.

Przybysz Piotr, Liberalna koncepcja jednostki a marksizm, w: Marksizm, liberalizm, próby wyjścia, red. Leszek Nowak, Piotr Przybysz, Zysk i S-ka, Poznań 1997, s. 135-157.

Renaissances Before the Renaissance. Cultural Revivals of Late Antiquity and the Middle Ages, red. Warren Treadgold, Stanford University Press, Stanford 1984.

Sahlins Marshall, Wyspy historii, Wydawnictwo UJ, Kraków 2006.

Sahlins Marshall, Jak myśla „tubylcy”. o kapitanie Cooku, na przykład, Wydawnictwo UJ, Kraków 2007.

Swianiewicz Jan, Możliwość makrohistorii. Braudel, Wallerstein, Deleuze, Wydawnictwo Naukowe UMK, Warszawa 2014.

Thode Heinrich, Franz von Assisi und die Anfänge der Kunst der Renaissance in Italien,

G. Grote'sche Verlagsbuchhandlung, Berlin 1885.

Toffanin Giuseppe, Che cosa fu l'Umanesimo, G.C. Sansoni, Firenze 1929.

Toffanin Giuseppe, Storia dell'Umanesimo, t. 1-3, Zanichelli, Bologna 1942.

Toynbee Arnold J., A Study of History, t. 9, Oxford University Press, Oxford 1957.

Trompf G.W., The Idea of Historical Recurrence in Western Thought. From Antiquity to the Reformation, University of California Publisher, Berkeley 1979.

Wolf Eric R., Europa i ludy bez historii, Wydawnictwo UJ, Kraków 2009.

Wrzosek Wojciech, Historia - kultura - metafora. Powstanie nieklasycznej historiografii, Leopoldinum, Wrocław 1995.

Biogram: mgr Konrad Adam Bielecki, Instytut Historii im. Tadeusza Manteuffla PAN (Warszawa). Obszar zainteresowań: kulturowa historia wczesnej nowożytności / antropologia historii, historia przyrodoznawstwa przed rewolucją naukową, historia druku i książki, metodologia nauk historycznych; kontakt: konradabielecki@gmail.com. 